\title{
The Case of the Disappearing E-Book: Academic Libraries and Subscription Packages
}

\section{Helen Georgas}

One of the standard models for e-book licensing in academic libraries is the subscription package. This study is a one-year analysis of "disappeared" titles from ebrary's Academic Complete ${ }^{\mathrm{TM}}$ collection. During 2013, 3462 titles were deleted. Deleted titles were mainly recent publications (published within the last ten years), with a high number of deletions within the broad subject areas of the social sciences $(H)$, language and literature $(P)$, and history ( $, D, E, F)$. Deleted titles were evenly divided between monographs published by popular presses, and monographs published by scholarly or university presses. It is recommended that deleted titles be closely monitored by subject librarians. Efficient library processes for handling deleted titles must also be implemented. Implications for libraries of changing e-book content are also discussed.

uring the last decade, e-books have become ubiquitous, and 95 percent of academic libraries currently carry them. ${ }^{1}$ One of the standard models for e-book licensing in academic libraries is the subscription package. ${ }^{2}$ In fact, "roughly half of all academic library e-book titles are acquired through package deals." ${ }^{3}$ Via the subscription package, publishers work with vendors such as EBSCO and ebrary to enable the licensing and leasing of their e-book titles to libraries. The benefits of such a model for libraries are many: it is less expensive than purchasing e-book titles individually, it includes a broad range of titles by many different publishers covering many different subjects, it allows for simultaneous access by multiple users, it eliminates the need to purchase print copies of a book, and it allows for remote $24 / 7$ access to content.

However, the e-book market is still an unstable one in which both "the availability of e-books to libraries and the terms on which e-books are made available have become sources of controversy between publishers and libraries." 4 The threat of e-books to traditional profit-making models has caused several large publishing houses to respond in a variety of ways: "from a hard limit on the number of times an e-book can circulate (HarperCollins), to vastly inflated prices for libraries (Random House), to simply not allowing frontlist e-books to go to libraries at all (Penguin, Simon \& Schuster, Macmillan). ${ }^{5}$ University and scholarly presses are also "under attack from several sources: stagnant sales of print books, growing popularity of e-books, downward pressure on

Helen Georgas is Reference Librarian and Assistant Professor at the Library of Brooklyn College of the City University of New York (CUNY); e-mail: HGeorgas@brooklyn.cuny.edu. (C2015 Helen Georgas, Attribution-NonCommercial (http://creativecommons.org/licenses/by-nc/3.0/) CC BY-NC. 
prices from e-book vendors, and the movement for open access." ${ }^{\prime 6}$ Because university presses "still get at least 90 to 95 percent of their sales revenue from printed books, even as the market for scholarly monographs continues to shrink," these traditional models in an era of e-books are "no longer sustainable."

As publishers struggle to respond to this shifting marketplace, contractual agreements between publishers and e-book subscription-package vendors are often subject to change. Publishers may decide to remove some of their content from subscription packages, or all of it altogether. In turn, licenses are such that "vendors are free to add or remove titles during the term of the agreement, often without notifying the subscribing institution. ${ }^{\prime 8}$ For example, in early 2012, because of the implementation of a full-text download capability that allowed users to download the full e-book to Adobe Digital Editions for fourteen days, four Canadian university presses removed all of their titles from the Canadian Electronic Library (CEL), a subscription-based ebook collection that many Canadian academic libraries subscribe to. ${ }^{9}$

While the argument can be made that, via e-book subscription packages, "much more quality content is being added in comparison to the number of titles that are being removed," the issue of disappearing content is a potentially significant one for academic libraries. ${ }^{10}$ To begin with, it is important to know which titles are being removed from the collection, along with which subject areas are being affected, since collection development, along with deselection (weeding), is normally the responsibility of the subject librarian or bibliographer.

Moving beyond collection development, what are the effects on library processes and workflows when content within e-book subscription packages is frequently changing? How can academic librarians promote and encourage use of e-books by faculty and students, especially as course material, if the e-books might, at any given moment, disappear? And what are the implications of leasing e-books for library values such as long-term access and preservation?

This study begins with a one-year analysis of "disappeared" titles from ebrary's Academic Complete ${ }^{\mathrm{TM}}$ collection at Brooklyn College of the City University of New York (CUNY). Were certain subject areas particularly affected? Which publishers were removed? Were the removed titles mainly scholarly, or were they titles published by popular presses? Were the removed monographs older publications, or were recent titles deleted as well?

By examining recent e-book removal trends within one particular subscription package, this study aims to provide librarians with a better understanding of the practical and theoretical implications of disappearing e-book content for academic libraries.

\section{About Brooklyn College and ebrary Academic Complete ${ }^{\mathrm{TM}}$}

Brooklyn College is a four-year college of approximately 17,000 undergraduate and graduate students that is part of the City University of New York (CUNY), a large, urban, public university comprising 540, 000 students and twenty-four community and senior colleges located throughout New York City.

ebrary describes its Academic Complete ${ }^{\mathrm{TM}}$ collection as one that includes more than 86,000 scholarly titles covering a wide range of subjects that thousands of universities, colleges, and community colleges from around the globe subscribe to. ${ }^{11}$ CUNY's Office of Library Services subscribes to ebrary Academic Complete ${ }^{\mathrm{TM}}$ centrally, so that each of its colleges, including Brooklyn College, has access to it.

The monograph budgets at the Brooklyn College Library have decreased significantly over the years. The library does not use approval plans, and only those titles that the subject librarians (also known as bibliographers, selectors, collection librarians, subject specialists, and other titles) believe will be useful to students for their coursework and/ 
or are requested by faculty are purchased (with some exceptions). As a result, much of the monograph collection is supplemented or grown via subscriptions to "big package" e-book collections such as ebrary Academic Complete ${ }^{\mathrm{TM}}$.

It is standard practice for ebrary to add and remove e-book titles from its ebrary Academic Complete ${ }^{\mathrm{TM}}$ collection. At the time of this study, ebrary removed titles on a monthly basis, so a monthly list of deleted titles was circulated by CUNY's Office of Library Services to its member libraries, including the Brooklyn College Library. ${ }^{12}$

\section{Literature Review}

William H. Walters acknowledges the many difficulties of shifting from ownership of content to leased access, including the impermanence of e-book collections, the inability for patrons to access titles once the institution has stopped subscribing, the fact that vendors do not provide librarians with any ability to determine which titles might be included in or removed from any given package, the fact that many academic e-books are released three to eighteen months after the corresponding print editions, and the fact that "big deal" packages "require libraries to pay for titles they don't want in order to get the ones they do want."13

In a discussion about how e-books may be more like serials than like traditional printed books, Rick Lugg stated that, via subscription packages, "reference works are updated frequently, and the subscription model makes sense to get up-to-date information. A subscription model is a burden for non-reference works with stable content, and it also puts a burden on the library to sustain the subscription."14

In terms of how deleted content affects library processes, Chris Armstrong and Ray Lonsdale discovered that "continuity of access is important for a number of reasons, and there are significant logistical and workflow issues if e-textbooks are added to, and subsequently removed from, catalogues, etc." ${ }^{15}$ In their article about the implementation of a new e-book workflow at the University of Nevada, Reno, Amalia Beisler and Lisa Kurt identified specific "end of life" procedures that needed to be followed when cancellations to an e-book subscription package took place and/or when publishers pulled titles from an e-book package or platform. ${ }^{16}$ Such procedures included the timely removal of the MARC record from the catalog and the removal or deactivation of links from the link resolver.

In chronicling the sudden withdrawal of all e-books published by several different university presses from a large Canadian subscription package, Ann Ludbrook outlined in detail how workflows were affected:

... cataloguing demands can mean that records remain outdated for a period of time. Collection decisions may need to be made depending on the use of and need for the title. If a chapter from an e-book is being used for teaching purposes, a mid-term removal by a vendor can result in both unexpected and upsetting access problems for instructors and students. It can sometimes be difficult for the library to even know how e-book resources are being utilized for teaching in the wider university community until there is a complaint received about loss of access. This can result in academic libraries having to put extra processes in place to make sure that e-books being used for teaching purposes are tracked in some way. ${ }^{17}$

In terms of usage studies of e-book collections, there are many. Abdoulaye Kaba and Raed Said studied the usage of ebrary across 18 government agencies, universities, and private institutions in the United Arab Emirates (UAE) and found that usage of ebrary was low and needed to be more heavily promoted. ${ }^{18}$ James Cory Tucker examined three-year 
usage data for ebrary and NetLibrary and found that ebrary had higher usage overall, perhaps due to the currency, variety, and size of its collection, and that the Schools of Liberal Arts and Business showed particularly high usage of the ebrary collection. ${ }^{19}$ Alain R. Lamothe, in a nine-year study of e-book usage at Laurentian University, found that "the size of an e-book collection was determined to show evidence of an extremely strong relationship with the level of usage e-books experienced." ${ }^{20}$ Kimberly R. Abrams studied usage of ebrary at Adelphi University and found that the Schools of Social Work and Nursing benefited most from the collection and that, overall, it was "a good value for both patrons and the university." ${ }^{21}$ Abrams also highlighted the importance of efficiently removing the records of deleted titles from the catalog and that, "even if the records are scrupulously managed, there can still be issues with patrons using a title one day and then not having access to it the next."22 Terry Bucknell analyzed usage of the SpringerLink 2010 e-book collection at the University of Liverpool and found that each subject area had been well used (with the exception of mathematics), that the number of unused titles continued to diminish each year, and that older titles continued to attract significant usage. ${ }^{23}$

While these studies of e-book packages, and ebrary in particular, have largely focused on usage, this study is unique in that it is the first to focus on and analyze removed titles from a subscription package of e-books (ebrary Academic Complete ${ }^{\mathrm{TM}}$ ).

\section{Methods}

Monthly deletion reports issued by CUNY's Office of Library Services were collected for ebrary Academic Complete ${ }^{\mathrm{TM}}$ for the calendar year 2013. All of the deleted titles were compiled into one Excel spreadsheet, totaled, and then analyzed by subject, publisher, and year of publication.

\begin{tabular}{|l|c|c|}
\hline \multicolumn{3}{|c|}{ TABLE 1 } \\
\hline \\
\hline \multicolumn{2}{|c|}{ Deleted Titles by Broad Subject Area/LC Classification } \\
\hline Social Sciences (H) & Deleted Titles & Percent \\
\hline Language \& Literature (P) & 632 & 18.3 \\
\hline History (C, D, E, F) & 578 & 16.7 \\
\hline Medicine (R) & 513 & 14.8 \\
\hline Science (Q) & 355 & 10.3 \\
\hline Technology (T) & 309 & 8.9 \\
\hline Philosophy, Psychology, Religion (B) & 305 & 8.8 \\
\hline Political Science (J) & 270 & 7.8 \\
\hline Law (K) & 88 & 2.5 \\
\hline Education (L) & 78 & 2.3 \\
\hline Geography, Anthropology, Recreation (G) & 73 & 2.1 \\
\hline Music (M) & 67 & 1.9 \\
\hline Agriculture (S) & 52 & 1.5 \\
\hline Fine Arts (N) & 49 & 1.4 \\
\hline Military \& Naval Science (U, V) & 47 & 1.4 \\
\hline Bibliography, Library Science, Information Resources (Z) & 31 & 0.9 \\
\hline General Works (A) & 2 & 0.4 \\
\hline
\end{tabular}




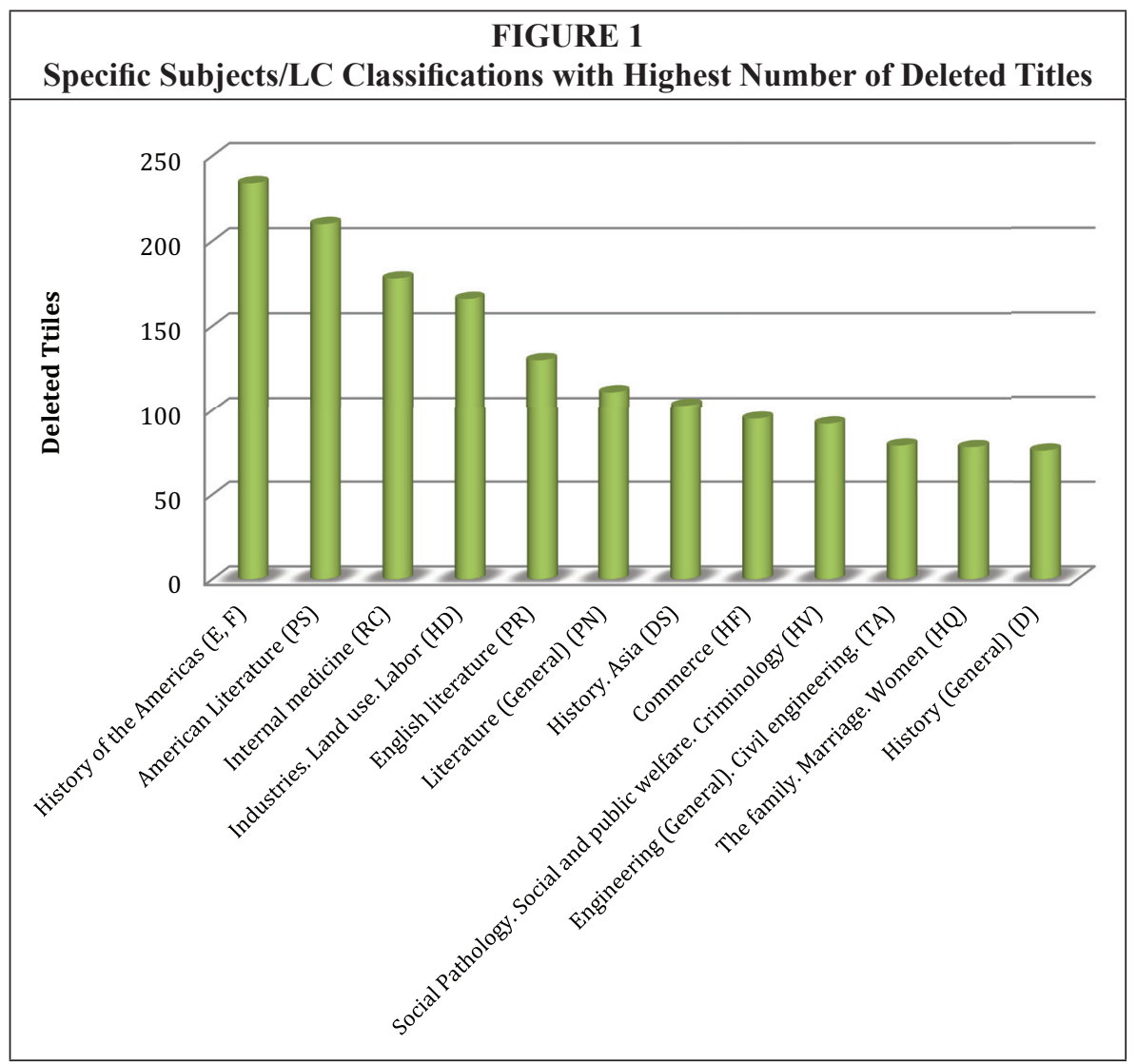

\section{Results and Discussion}

During 2013, ebrary removed a total of 3,462 titles from the Academic Complete ${ }^{\mathrm{TM}}$ collection. As of January 2014, there were approximately 115,000 titles included in the Academic Complete ${ }^{\mathrm{TM}}$ collection. ${ }^{24}$ Thus, the total number of deleted titles accounted for approximately 3 percent of the collection.

\section{Deleted Titles by Subject}

In terms of broad subject area, many of the deleted titles were from the social sciences (LC subject class: $\mathrm{H})$, followed closely by language and literature $(\mathrm{P})$, and history $(\mathrm{C}$, D, E, F) (see table 1). Monographs about medicine accounted for just over 10 percent of deleted titles, and science- or math-related monographs $(\mathrm{Q})$, along with monographs about technology $(\mathrm{T})$, each accounted for almost 9 percent of deleted titles. Titles in philosophy, psychology, and religion (B) accounted for almost 8 percent of deleted titles.

On a more granular level, the subject with the highest number of deleted titles was history of the Americas (E, F, 214 titles), followed by American literature (PS, 210 titles), and then by internal medicine (RC, 178 titles) (see figure 1). Titles related to English literature (PR, 130 titles) and general literature (PN, 111 titles) also made the "top twelve" list of deleted titles by subject, as did Asian history (DS, 103 titles), and general history ( $D, 76$ titles).

Given these numbers, literature was considerably affected, as was history. In general, subjects within the humanities and social sciences were significantly impacted 
with regard to the removed content. This may be surprising given that, in addition to contract renegotiations between publishers and vendors, the perception is that titles are often removed from ebrary (and, by extension, other large e-book subscription packages) because they are out of date. Although recent titles are certainly important in the humanities and social sciences, older material is still relevant.

Making sure that content is up to date and thus removing "older" titles may account for the deletions of medical (R), math \& science (Q), and technology (T) titles. However, one could also argue that it is surprising that these subjects did not account for a higher overall percentage of the deleted titles. Furthermore, since books about software (such as Microsoft Office and Adobe Photoshop) are so frequently updated (and need to be to stay relevant), the QA subject area was examined, specifically QA76. That is where the majority of such software guides would be classified. Only thirty titles (less than $1 \%$ ) of the deleted titles fell within the QA76 call number range.

In terms of subject area and usage, it has been found that e-book acceptance is "slightly higher...in the sciences, but with very similar acceptance rates across all disciplines." ${ }^{25}$ Knowing that e-book usage is similar across all the disciplines means that subject librarians for the social sciences and humanities - not just subject librarians for the sciences - need to seriously consider the high number of deleted titles in their areas. It may be that there are specific areas that are particularly affected, and title-by-title purchasing may need to take place to replace the deleted content.

\section{Deleted Titles by Publisher Type}

Three categories of publisher were created (Popular/Trade, Scholarly/Scientific, and University Press), and each publisher was categorized by type.

A very slight majority of deleted titles were from popular presses (50.9\%) (see table 2). The rest of the deleted titles (49.2\%) were from either scholarly/scientific or university presses.

\begin{tabular}{|l|c|c|c|}
\hline \multicolumn{4}{|c|}{ TABLE 2 } \\
& Deleted Titles by Publisher Type \\
\hline & Popular/Trade & Scholarly/ Scientific & University Press \\
\hline Deleted Titles & 1,762 & 1,053 & 647 \\
\hline Percent & 50.9 & 30.4 & 18.8 \\
\hline
\end{tabular}

Since the focus for academic libraries must necessarily be the acquisition of monographs published by scholarly and/or university presses, the high percentage of deletions of academic titles is significant. The deletion of a large number of popular press titles is also significant, however, given that academic libraries, especially those with smaller (or decreasing) budgets, may rely on supplementing their academic collections with popular press titles that may appeal to, and get used by, undergraduate students.

\section{Popular/Trade Publishers}

Five of the six popular/trade publishing companies with the highest number of deleted titles (Knopf, Random House, Doubleday, Vintage Books, and Pantheon Books) are all owned by the same parent company, Random House LLC (see table 3). One might argue, then, that all of these deleted titles are by a single publisher: Random House LLC.

Indeed, with the "big six" publishers recently reduced to the "big five" (Random House LLC merged with Penguin Group in July 2013), it becomes a difficult and timeconsuming task to attempt to categorize all of the various imprints and subsidiaries by 


\begin{tabular}{|l|c|c|c|c|c|c|}
\hline \multicolumn{7}{|c|}{ TABLE 3 } \\
\hline & Knopf & $\begin{array}{c}\text { Random } \\
\text { House }\end{array}$ & Doubleday & $\begin{array}{c}\text { Vintage } \\
\text { Books }\end{array}$ & $\begin{array}{c}\text { Modern } \\
\text { Library }\end{array}$ & $\begin{array}{c}\text { Pantheon } \\
\text { Books }\end{array}$ \\
\hline $\begin{array}{l}\text { Deleted } \\
\text { Titles }\end{array}$ & 264 & 166 & 129 & 123 & 118 & 79 \\
\hline Percent & 7.6 & 4.8 & 3.7 & 3.6 & 3.4 & 2.3 \\
\hline
\end{tabular}

publisher. Insofar as the author could determine, Knopf Doubleday Publishing Group (again, owned by Random House LLC) in turn owns the following imprints: Anchor Books, Schocken Books, and Nan A. Talese. Crown Publishing Group is a subsidiary of Random House LLC and owns Three Rivers Press. Given this, 1,025 out of the 3,642 deleted titles (29.6\%) were published by a single publisher: Random House LLC.

As is perhaps suggested by these data, if a parent company decides to pull titles from a subscription package, it is possible that many, if not all of its imprints, may be subject to removal as well.

\section{Scholarly/Scientific Publishers}

Karger Publishers was the scholarly/scientific press with the highest number of removed titles, followed closely by the American Society of Civil Engineers (ASCE) (see table 4).

\begin{tabular}{|l|c|c|c|c|c|c|}
\hline \multicolumn{7}{|c|}{ TABLE 4 } \\
\hline Scholarly/Scientific Publishers with Highest Number of Deleted Titles \\
\hline & $\begin{array}{c}\text { Karger } \\
\text { Publishers }\end{array}$ & $\begin{array}{c}\text { American } \\
\text { Society of Civil } \\
\text { Engineers } \\
\text { (ASCE) }\end{array}$ & $\begin{array}{c}\text { Island } \\
\text { Press }\end{array}$ & $\begin{array}{c}\text { Open } \\
\text { University } \\
\text { Press }\end{array}$ & $\begin{array}{c}\text { World } \\
\text { Scientific } \\
\text { Publishing }\end{array}$ & $\begin{array}{c}\text { Manson } \\
\text { Publishing }\end{array}$ \\
\hline $\begin{array}{l}\text { Deleted } \\
\text { Titles }\end{array}$ & 256 & 208 & 116 & 65 & 59 & 51 \\
\hline Percent & 7.4 & 6.0 & 3.4 & 1.9 & 1.7 & 1.5 \\
\hline
\end{tabular}

Karger Publishers describes itself as a "leading biomedical publisher" of "books covering basic and clinical research subjects across the medical spectrum." 26 In considering the deletions by subject, it makes sense that, with Karger Publishers' titles removed, many of the books were broadly about medicine (R) or, more specifically, about internal medicine (RC). Indeed, in reviewing most of Karger's deleted titles, a large number of them (112 titles) were in the RC subject area.

The American Society of Civil Engineers (ASCE) now offers individuals and libraries the option to purchase more than 300 of their e-books directly via their site. This may be the reason that so many of their titles were removed from ebrary in 2013 (though, as of July 2014, 23 titles published by ASCE were still accessible via ebrary). It is not uncommon for individual presses or publishers to create their own platforms for the selling of their e-book titles. This may be one reason for the large-scale removal of titles from ebrary and, by extension, other large subscription packages. Given ebrary's popularity, however, choosing to make e-books available via both ebrary and the publisher's own platform may be a way to increase exposure and access to a particular publisher's titles.

In examining the other scholarly/scientific publishers with a high number of deleted titles, it was found that Island Press is "a nonprofit, environmental publisher" that "spe- 
cializes in natural history, ecology, conservation, and the built environment." ${ }^{27}$ Open University Press publishes "educational books and resources within the fields of Education, Nursing, Social Work, Study Skills, Psychology, Coaching, Counselling, and many other social science disciplines." ${ }^{28}$ World Scientific Publishing describes itself as "a leading international publisher in science, technology and medicine." ${ }^{29}$ Manson Publishing (owned by CRC Press) publishes titles in "medicine, veterinary medicine and the sciences." 30

In light of these publisher descriptions, subject librarians responsible for collection development in areas such as environmental studies, veterinary medicine, education, nursing, and other allied-health or social-service disciplines may wish to closely examine the specific titles deleted by these publishers, so that they may respond accordingly.

\section{University Presses}

In examining the deleted university press titles, monographs published by the University of Chicago Press accounted for the highest number of deleted e-books (444 titles, $12.8 \%$ ) (see table 5).

\begin{tabular}{|l|c|c|c|c|c|c|}
\hline \multicolumn{7}{|c|}{ TABLE 5 } \\
\hline & $\begin{array}{c}\text { University Presses with Highest Number of Deleted Titles } \\
\text { of Chicago } \\
\text { Press }\end{array}$ & $\begin{array}{c}\text { Cornell } \\
\text { University } \\
\text { Press }\end{array}$ & $\begin{array}{c}\text { Columbia } \\
\text { University } \\
\text { Press }\end{array}$ & $\begin{array}{c}\text { Oxford } \\
\text { University } \\
\text { Press }\end{array}$ & $\begin{array}{c}\text { Harvard } \\
\text { University } \\
\text { Press }\end{array}$ & $\begin{array}{c}\text { Cambridge } \\
\text { University } \\
\text { Press }\end{array}$ \\
\hline $\begin{array}{l}\text { Deleted } \\
\text { Titles }\end{array}$ & 444 & 45 & 41 & 34 & 30 & 20 \\
\hline Percent & 12.8 & 1.3 & 1.2 & 1.0 & 0.9 & 0.6 \\
\hline
\end{tabular}

In a newsletter issued just two years earlier, in 2011, ebrary announced the addition of 16,000 titles, an unprecedented amount, including works, for the first time, by the University of Chicago Press, Oxford University Press, and Harvard University Press, among others. ${ }^{31}$ The inclusion of such well-respected and high-use university presses such as the University of Chicago may have enticed libraries to acquire packages such as ebrary Academic Complete ${ }^{\mathrm{TM}}$, only to have that same press pull a significant number of its titles just two years later. It would be interesting to know, definitively, why so many of this publisher's titles were removed from ebrary in 2013. Maximizing revenue was likely an issue, as it is for so many university and nonprofit presses.

For libraries, however, the University of Chicago Press's large-scale removal demonstrates that there are no guarantees for long-term inclusion of titles by any single publisher. This is something that librarians must seriously take into account before subscribing to such packages.

In looking at the subjects of the deleted University of Chicago titles, these are approximately in line with the overall subject deletions. The majority of the deleted titles, by broad subject area, were in the social sciences $(\mathrm{H})$ (101 titles), language and literature $(\mathrm{P})$ (84 titles), mathematics and science (Q) (58 titles), and history (C, D, E, F) (50 titles). Again, on a more granular level, the subjects deleted reflect the overall deleted titles, with a highest number of deletions in general literature (PN) (27 titles), American literature (PS) (19 titles), the family/marriage/women (HQ) (18 titles), general science and mathematics (Q) (17 titles), and social pathology/ social and public welfare/ criminology (HV) (17 titles).

Although the University of Chicago Press still has many of its monographs available via ebrary (1,002 titles as of July 2014), it is also interesting to note that they are one of a short list of presses in ebrary that currently do not allow full-document downloading 
of any of their titles. So, in addition to removing a large number of titles just two years after their initial inclusion, the University of Chicago Press limits access to those titles it continues to include. Again, libraries need to take all such factors into account when deciding whether to subscribe to large e-book packages such as ebrary Academic Complete ${ }^{\mathrm{TM}}$.

Because this study did not take into account usage of these deleted titles, we can look to Booker's study of ebrary usage, which provided a list of ten publishers that had the highest use..$^{32}$ Oxford University Press, the University of Chicago Press, and Cambridge University Press were all on that "top ten" list, thus highlighting the fact that many of the titles deleted by ebrary in 2013 were by high-use university presses. In addition, nine of the top ten high-use publishers in Booker's study were scholarly or university presses, again emphasizing the importance of academic monographs to students and faculty in college or university settings.

\section{Deleted Titles by Year of Publication}

The overwhelming majority of the deleted titles were relatively recent-published in 2000 or later (91.1\%) (see table 6). Indeed, 2,639 (76.2\%) of the deleted monographs were published within the last decade (2003-2013). Very few of the deleted titles were what could be considered "older" monographs. In fact, fewer than 10 percent of the deleted monographs were published before 2000. Looking at the oldest deleted titles - those published in the 1960s and 1970s - it was noted that these titles were humanities and social science monographs published by the University of Chicago Press.

Again, one might expect that older titles would account for the greatest number of deletions, but this is not the case. The single year of publication with the highest number of deleted titles was 2005 (434, 12.5\%), followed closely by 2004 (385, 11.1\%) (see figure 2).

\begin{tabular}{|l|c|c|c|c|c|c|}
\hline \multicolumn{7}{|c|}{ TABLE 6 } \\
\hline & $\mathbf{1 9 6 0 s}$ & $\mathbf{1 9 7 0 s}$ & $\mathbf{1 9 8 0 s}$ & $\mathbf{1 9 9 0 s}$ & $\mathbf{2 0 0 0 s}$ & $\mathbf{2 0 1 0 s}$ \\
\hline Deleted Titles & 6 & 2 & 47 & 252 & 2,664 & 491 \\
\hline Percent & 0.2 & 0.1 & 1.4 & 7.3 & 76.9 & 14.2 \\
\hline
\end{tabular}

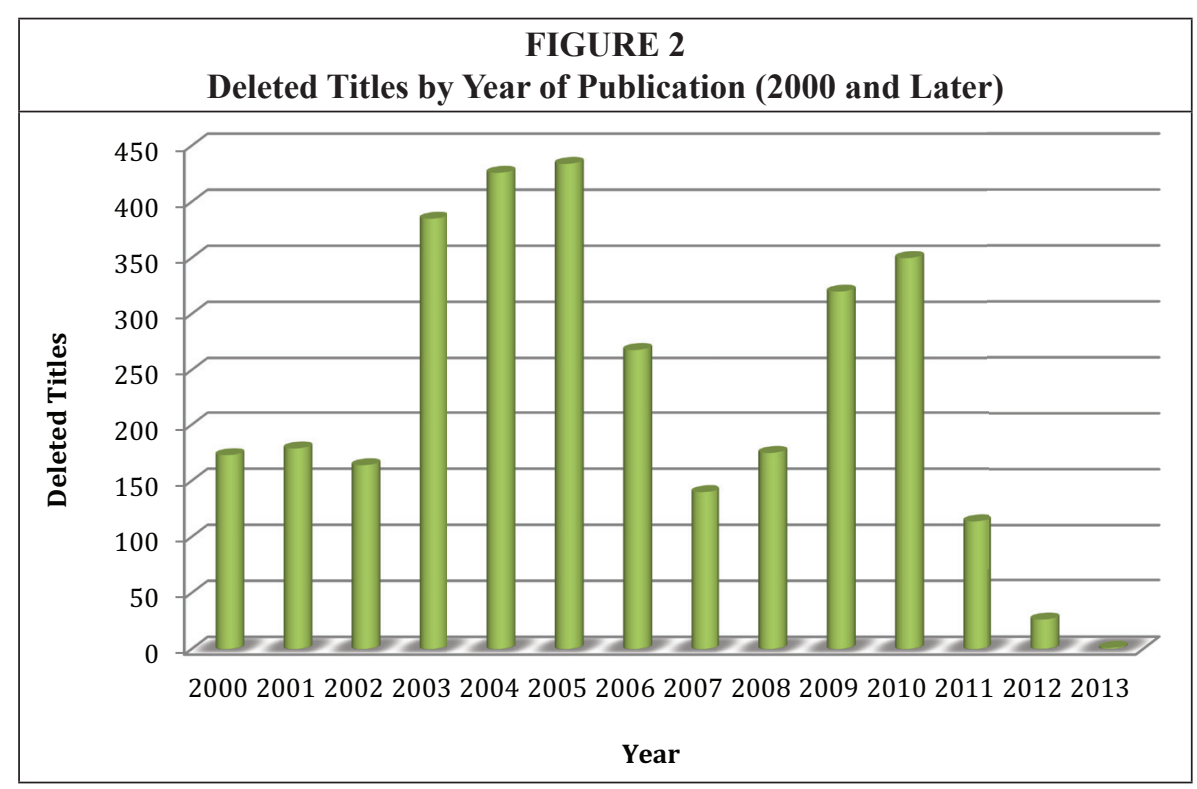


Since it has already been determined that many of the deleted titles were in subjects within the humanities and social sciences - where older monographs remain relevant-this observation is important. Even within the sciences, it has been found that e-books that are more than a few years old continue to receive high use. ${ }^{33}$ In fact, when SpringerLink's 2010 e-book collection was examined at the University of Liverpool, it was found that "titles published in 2007 accounted for more total chapter downloads than any other year, and that the years 2006 and 2005 also contributed heavily to the overall usage." ${ }^{34}$ Of course, other studies suggest the opposite: that "the relevance of material to researchers is directly proportional to date of publication," and that older titles receive significantly lower use. ${ }^{35}$

Regardless, the implication is that currency or date of publication of deleted titles is a variable that needs to be considered when examining removed content.

\section{Monitoring Deleted Titles}

Librarians "have expressed a strong preference for title-by-title selection" over subscribing to big-package e-book collections. ${ }^{36}$ However, subscription packages allow librarians to avoid the speculative purchasing of "just in case" titles-especially if monograph budgets are small, as is increasingly the case. ${ }^{37}$ This allows the subject librarian to avoid anticipating what might get used, and instead to focus (shrinking) budgets on purchasing those titles that are needed by students and faculty.

However, subscribing to large e-book packages may merely shift the emphasis from time spent on individual title selection, to time spent on monitoring titles in such packages. Subject librarians should be provided usage reports for e-book subscription packages regularly. For those titles that are most heavily used, the subject librarian may decide to purchase an archival copy of a particular monograph, either in print or as an e-book. This will ensure that those titles that are most heavily used by faculty and students will remain in the library collection permanently.

In addition to regular usage reports, subject librarians should have access to regular deletion reports. It is essential to monitor which heavily used (or simply used) titles have been removed from the collection and to see if a specific subject area has been particularly affected. For example, this study of deleted titles from ebrary Academic Complete ${ }^{\mathrm{TM}}$ in 2013 shows that a high number of deleted titles fell under the broad subject area of language and literature (P) (578 titles, 16.7 percent of the total number of deleted titles). Upon closer examination, it was discovered that monographs within American Literature (PS) and English literature (PR) were particularly affected, with $210(6.1 \%)$ and 130 titles $(3.8 \%)$ removed from the collection, respectively.

Deleted titles by publisher should also be examined. Given that the University of Chicago Press removed an astounding 444 titles from ebrary in 2013, the subject librarians at a given college or university may wish to consider what actions need to be taken when a single press removes a large number of its titles. Since university and scholarly press titles are more likely to be used by faculty and students (over popular press titles), subject librarians may wish to alert faculty that a particular press's titles have been removed from a collection, along with a plan to replace titles of particular interest or importance.

This study also suggests that, along with subject and publisher, librarians may wish to monitor the dates of publication of deleted titles, since the majority of titles removed from ebrary were recent titles published within the last decade, and that recency has been shown to be a factor that influences use. ${ }^{38}$ There may be a perception that vendors are largely removing e-books in the sciences and technology-such as software guides - that are older and/or in need of updating, but such is not the case. 
Of course, subject librarians will also need to consider whether every removed title is of value. As one librarian stated in a 2012 e-book usage survey, subscription packages such as ebrary yield:

"...a low cost per title, but we have no control over the content that is added to our collection. Many highly desired titles are not available by subscription and the collection includes many low value, low quality titles that we would never acquire independently." ${ }^{\prime 39}$

This belief is shared by Walters, who writes that "most e-book packages include a substantial number of titles that are not relevant to the needs of the subscribing library, including backlist titles that would not generate much revenue if offered individually." ${ }^{40}$

To minimize the amount of time and effort that would be required to compile such reports on a regular basis, one possible solution would be to designate a single person within the library to compile, sort, and present usage and deleted titles (by subject, publisher, and year of publication) in one Excel spreadsheet. This report could then be distributed to all of the subject librarians. In this way, each subject librarian could minimize the amount of time spent on individually preparing reports, instead focusing their time and attention on replacing important or high-use e-book titles that have been removed from the collection.

\section{Collection Development and Weeding}

What are the implications for libraries when collection development and weeding is effectively outsourced to the vendors of these large e-book subscription packages? Such duties are normally the responsibility of the subject librarian, and much time and consideration go into the collection building, collection management, and weeding processes. Factors normally taken into account before acquiring or removing a title include: subject relevance, authorship, content quality, publisher, date of publication, potential use by students and faculty, and long-term value. Whereas it seems unlikely that such factors are the same ones being considered by vendors on a title-by-title basis when e-books are added to, or subsequently removed from, large packages. Though vendors such as ebrary may state otherwise, titles are often removed because a contract has been renegotiated and/or a particular press or publisher has decided to remove its titles from a collection. Indeed, this study shows that it is not just older or updated titles that were removed, but rather recent titles from the social sciences and humanities-subject areas where both recent and older titles are important.

In attempting to determine ebrary's collection development and/or weeding policies - if such policies exist - the only information available via their website outlined their goal in "partnering with the world's leading publishers to make authoritative ebooks available." ${ }^{41}$ More specifically, in describing their Academic Complete ${ }^{\mathrm{TM}}$ collection, they refer to a "strong focus on titles recommended for research," "expert academic librarian selectors," and say that it "offers a high-quality collection of e-books from leading scholarly publishers across all academic subject areas." 42

\section{Use of Subscription-Package E-Books in Courses}

It is especially problematic for students and faculty when e-books that are being used as required or recommended reading material for classes are removed from the collection. Academic libraries now regularly encounter situations where a course-assigned e-book disappears midsemester. It can be difficult (if not impossible) for a library to know when e-books are being used for teaching until a professor or student complains that the content is no longer accessible. As Ksenija Minčić-Obradović has pointed out, 
"this creates difficulties when a lecturer chooses an electronic title for recommended reading and then, half-way through the course, without any notice or explanation from the vendor or publisher, the e-book is no longer available." 43

This issue of disappearing course material is especially relevant in this era of everincreasing textbook fees and the push to provide college students with access to inexpensive (or open) course materials. In addition, when e-book content is pulled from platforms, "it undermines the stability and trust of the vendor and platform, giving the user a negative experience. ${ }^{44}$ Sudden removal of content also makes "the library" look bad and jeopardizes relationships between librarians and the faculty and students they serve-relationships that librarians work very hard to cultivate.

It may be that academic librarians should discourage the use of subscription-based ebooks as course materials and focus their attention on promoting the use of truly owned, or perpetual access, e-book titles. This seems ridiculous, however, given the money libraries spend on subscribing to collections such as ebrary Academic Complete ${ }^{\mathrm{TM}}$.

At the very least, faculty and students need to be informed that the removal of a title from an e-book subscription collection is always a possibility. For example, in its current guidelines for e-reserves, Ithaca College states: "Please note that ebook titles in current collections are subject to removal by the vendor at any time." ${ }^{45}$

\section{Library Processes and Workflows}

When e-book titles disappear, other library processes and workflows are also affected. The removal of titles "is an additional process that has to be added to the agenda for systems librarians every month." 46 The delay between content being removed from a subscription package and notification of a title's removal means that the book may remain in the catalog for some time after it has disappeared. As a result, deletions must be communicated and updated in the catalog as quickly as possible so that users are not misled into thinking a library continues to have a title. In short, "batch deletion is crucial, given the fluid nature of digital resources." ${ }^{47}$

Going further, a librarywide process for handling deleted materials from e-book subscription packages must be implemented. The process should allow everyonevendors, systems librarians, collection managers, catalogers, electronic resource librarians, subject librarians, reference librarians, faculty, and students - to work together systematically and effectively each time an e-book title is removed. As Beisler and Kurt acknowledged, "procedures are more or less the same for planned end of life (such as the cancellation of a package) as for titles that abruptly disappear (such as when publishers pull titles from a platform or package). What is key is the ongoing communication that the task force's work has put in place." ${ }^{48}$ This increased communication should also include the ability of patrons to easily report linkage problems, as well as the regular checking of e-book links in the catalog. ${ }^{49}$

Guidelines must also be put in place for those e-book titles that might be requested for reserve, if such use is permitted by the vendor. Web pages for library service units should reflect this awareness (of titles potentially being deleted) and what it might mean for its users. In an ideal world, the subject librarian or faculty liaison would be able to immediately inform the faculty member when a title is removed-or, going even further, a vendor should be able to provide libraries with a list of projected deletions allowing for some time before they're actually removed from the collection. As it happens, such advance updates usually only happen when a particularly large press or publisher is removing all of their titles from a collection.

\section{“Ownership,” Long-Term Access, and Preservation}

Subscription e-book packages preclude ownership, and many of the attendant rights 
of ownership, such as long-term access to a book by a library's patrons, the lending of books to patrons at other libraries (via interlibrary loan), and, in some cases, access to the entire book.

As Angela M. Carreño and Bill Maltarich have stated, libraries "should not only be concerned with access to content, but continued and perpetual access to content." ${ }^{50}$ When libraries only lease content-as they do via subscription packages - then how can they ensure future access to and preservation of that content? Charles Hamaker takes these issues a step further and states: "The problem, mostly unaddressed, of long-term retention of electronic books, is critical. It is not acceptable for the publisher or aggregator to also be the 'guarantor' of the long-term security" of titles. ${ }^{51}$ The values of publishers and vendors are not necessarily in line with those of libraries. Hamaker continues: "Because a publisher or aggregator has the expectation of future revenue from its stock doesn't mean it will hold it indefinitely when the ebook is no longer profitable." 52 Indeed, we do not currently look to publishers for access to out-of-print copies of books - we look to libraries. The same should be said of e-books.

One possible example to follow is New York University's decision to work directly with both ebrary and publishers. "Book aggregators sell publisher content under different restraints, terms, and conditions from what publishers may offer when selling content directly, and certainly only publishers themselves have the authority to alter standard permissions as part of purchase negotiations. ${ }^{153} \mathrm{NYU}$ uses the ebrary platform to acquire titles that are not currently licensed by ebrary and, by working directly with the publishers, to provide perpetual access to a large collection of e-books. That said, NYU is an extremely large research institution, and its libraries have a larger budget than many other academic libraries in the country. Such capital provides NYU with the bargaining power to negotiate directly with publishers but makes the large-scale replication or adoption of such a model by academic libraries unlikely.

Perhaps a more likely scenario for academic libraries is to move from subscription models to perpetual-access models and/or models that have limited digital restrictions management (DRM) and allow full-text downloading, at a chapter level, of the entire book. If academic libraries begin to make this shift, this may put pressure on vendors such as ebrary and EBSCO to enable less limited access to their e-books or, at the very least, force them to be more transparent and communicative about the regularly changing content of their subscription collections.

\section{Disappearing E-Books and Information Literacy}

Given the popularity of e-book subscription packages such as ebrary Academic Complete $^{\mathrm{TM}}$, how do we acknowledge the disappearing e-book phenomenon with students? This may be an opportunity for reference and instruction librarians to engage students with information literacy and/or threshold concepts involving e-books (and, by extension, digital content), ownership, licensing, leasing, and perpetual access to information. Students could be guided into thinking about what goes on behind the scenes from publisher to vendor to library to user. Why, when we "buy" an e-book, can we not necessarily access the whole thing? Or why do publishers and/or vendors make such access difficult? Students in the library classroom could be encouraged to consider the effects on their own learning when restrictions are placed on their access to information, or when content (be it required reading for a course or not) suddenly disappears.

\section{Conclusions}

During 2013, 3,462 titles were deleted from the ebrary Academic Complete ${ }^{\mathrm{TM}}$ collection subscribed to by Brooklyn College. These deleted titles were mainly recent publications (published within the last ten years), with a high number of deletions within the broad 
subject areas of the social sciences $(\mathrm{H})$, language and literature $(\mathrm{P})$, and history $(\mathrm{C}, \mathrm{D}$, E, F). Specific subject areas with a high number of deleted titles included history of the Americas (E, F), American literature (PS), and internal medicine (RC). The deleted monographs were evenly divided between titles published by popular/trade presses and titles published by scholarly/scientific or university presses. Random House LLC and its various imprints accounted for at least 1,025 of deleted titles, followed by the University of Chicago Press (444 deleted titles), Karger Publishing (256 deleted titles), and the American Society of Civil Engineers (ASCE) (208 deleted titles).

Given these observations, it is recommended that deleted titles should be closely monitored by subject librarians. Even though subscription packages are a convenient and relatively inexpensive way to provide access to a large collection of e-books, such packages may create more work for subject librarians because of the necessary monitoring and subsequent decision making that must take place. Efficient processes or workflows must also be implemented so that all of the necessary stakeholderssystems librarians, collection managers, subject librarians, reference librarians, and patrons - can be made aware and respond accordingly when an e-book title is removed from the collection.

Looked at another way, if the single most important factor influencing the usage of e-books is the size of the collection, then, as long as ebrary keeps getting bigger, it will get used, regardless of whether subject librarians monitor it or not. ${ }^{54}$ Subject librarians could focus their efforts on persuading vendors to provide collections with less restricted DRM, improved full-text download capabilities, and more stable content.

\section{Future Research}

As William H. Walters emphasized, "decisions about e-books should be based on solid evidence." ${ }^{55}$ While many articles about the controversies surrounding e-books have been published, along with usage studies at individual institutions, the profession would benefit from "big picture" usage studies across institutions and vendors (ebrary, EBSCO, Springer, and so on), along with evidence-informed studies that compare e-book content across subscription packages (both added and deleted titles), that evaluate the ease of use of the various e-book models (subscription, perpetual-access, patron-driven), and that examine user preferences and needs along with which platforms best ensure and protect their rights as e-book readers (access, privacy).

More specific questions that might be considered include: How many of the e-books in subscription (and other) packages are titles released long after the corresponding print editions? What percentage of e-book collections are being used as required reading or course material? What is the cost per use of each title within a particular collection, given that such packages include a long list of titles that libraries would not otherwise purchase? If certain titles are redundant across collections, and academic libraries are often likely to subscribe to multiple packages simultaneously, what percentage of each package offers unique content?

In closing, if we continue to cede much of our selection and collection management responsibilities as librarians to e-book vendors, we should gather evidence that will enable us to make informed decisions about which rights and privileges (ownership, access, long-term preservation, ease of use) we are and are not willing to give up.

\section{Notes}

1. EBook Usage in U.S. Academic Libraries (New York: Library Journal, 2012), available online at www.thedigitalshift.com/research/ebook-usage-reports/academic/ [accessed 8 July 2014].

2. Ibid.

3. William H. Walters, "E-books in Academic Libraries: Challenges for Acquisition and Collection Management," portal: Libraries \& the Academy 13, no. 2 (2013): 203. 
4. Stanley M. Besen and Sheila Nataraj Kirby, "Library Demand for E-books and E-book Pricing: An Economic Analysis, Journal of Scholarly Publishing 45, no. 2 (2014): 128.

5. John W. Maxwell, "E-Book Logic: We Can Do Better," Papers of the Bibliographical Society of Canada 51, no. 1 (2013): 38.

6. Lynne Withey et al., "Sustaining Scholarly Publishing: New Business Models for University Presses, A Report of the AAUP Task Force on Economic Models for Scholarly Publishing," Journal of Scholarly Publishing 42, no. 4 (2011): 406.

7. Ibid., 437,433 .

8. Walters, "E-books in Academic Libraries," 203.

9. Ann Ludbrook, "Canada's E-book Withdrawal: Digital Rights Management and the Canadian Electronic Library," Feliciter 59, no. 1 (2013): 18-20.

10. Kimberly R. Abrams, "An Analysis of ebrary Academic Complete at Adelphi University," Collection Building 33, no. 1 (2014): 14.

11. ebrary, "Academic Complete: The First and Still the Best," available at www.ebrary.com/ corp/collateral/en/Brochure_Web/ebrary_academic_first.pdf [accessed 31 July 2014]; phone conversation with ebrary representative, 31 July 2014.

12. As of December 2014, ebrary moved to a model of twice-yearly deletions (with the exception of publisher-driven removals, which may take place out of cycle).

13. Walters, "E-books in Academic Libraries," 196.

14. Kim Armstrong, Bob Nardini, Peter McCracken, Rick Lugg, and Kay G. Johnson, "When Did (E)-books Become Serials?" Serials Librarian 56, no. 1 (2009): 137.

15. Chris Armstrong and Ray Lonsdale, E-book Collection Management in UK University Libraries: Focus Groups Report (Information Automation Limited, Final Report, November 2009), 24, available online at http://observatory.jiscebooks.org/reports/e-book-collection-management-inuk-university-libraries-focus-groups-report/ [accessed 8 July 2014].

16. Amalia Beisler and Lisa Kurt, "E-Book Workflow from Inquiry to Access: Facing the Challenges to Implementing E-Book Access at the University of Nevada, Reno," Collaborative Librarianship 4, no. 3 (2012): 96-116.

17. Ludbrook, "Canada's E-book Withdrawal," 19.

18. Abdoulaye Kaba and Raed Said, "Usage of Electronic Books: AStudy of ebrary Database in the United Arab Emirates," DESIDOC Journal of Library \& Information Technology 32, no. 2 (2012): 95-100.

19. James Cory Booker, "Ebook Collection Analysis: Subject and Publisher Trends," Collection Building 31, no. 2 (2012): 40-48.

20. Alain R. Lamothe, "Factors Influencing the Usage of an Electronic Book Collection: Size of the E-book Collection, the Student Population, and the Faculty Population," College \& Research Libraries 74, no. 1 (2013): 39.

21. Kimberly R. Abrams, "An Analysis of ebrary Academic Complete at Adelphi University," Collection Building 33, no. 1 (2014): 14.

22. Ibid., 14.

23. Terry Bucknell, "The 'Big Deal' Approach to Acquiring E-books: A Usage-Based Study," Serials 23, no. 2 (2010): 126-34.

24. E-mail exchange with ebrary representative, 9 December 2014.

25. Deborah Lenares, Steve Smith, and Robert W. Boissy, "Springer eBooks: eBook Use and Acceptance in an Undergraduate Institution" (Springer, White Papers for Librarians, 2013), 6, available online at www.springer.com/librarians/e-content/ebooks?SGWID=0-40791-12-980350-0 [accessed 8 July 2014].

26. Karger Publishing, available online at www.karger.com [accessed 30 July 2014].

27. Island Press, available online at www.islandpress.com [accessed 30 July 2014].

28. Open University Press, available online at www.mheducation.co.uk/openup/ [accessed 31 July 2014]. 2014].

29. World Scientific Publishing, available online at www.worldscientific.com [accessed 31 July

30. Manson Publishing, available online at http://igpweb.igpublish.com/igp/manson-publishing [accessed 31 July 2014].

31. ebrary, "Press Release" (24 June 2011), available online at www.ebrary.com/corp/newspdf/ ebrary_AC_70K.pdf [accessed 28 July 2014].

32. Booker, "Ebook Collection Analysis."

33. Terry Bucknell, "The ‘Big Deal' Approach to Acquiring E-books," 126-34.

34. Ibid., 128.

35. Catherine S. Herlihy and Hua Yi, "E-Books in Academic Libraries: How Does Currency Affect Usage?" New Library World 111, no. 9/10 (2010): 371-80.

36. Walters, "E-books in Academic Libraries," 203. 
37. Steve Sharp and Sarah Thompson, "'Just in Case' vs 'Just in Time': E-Book Purchasing Models," Serials 23, no. 3 (2010): 21-25.

38. Herlihy and Yi, "E-Books in Academic Libraries."

39. EBook Usage in U.S. Academic Libraries, 63.

40. Walters, "E-books in Academic Libraries," 203.

41. ebrary, "ebrary Partners," available online at www.ebrary.com/corp/partners.jsp [accessed 28 July 2014].

42. ebrary, "Academic Complete: The First and Still the Best."

43. Ksenija Minčić-Obradović, "Ten Years On: E-books at the University of Auckland Library," Serials 22, no. 3 (2009, suppl.): 26.

44. Beisler and Kurt, "E-Book Workflow from Inquiry to Access," 107.

45. Ithaca College Library, "Reserves," available online at http://ithacalibrary.com/services/ reserves.php [accessed 1 August 2014]

46. Abrams, "An Analysis of ebrary Academic Complete," 14.

47. Rebecca L. Mugridge and Jeff Edmunds, "Batchloading MARC Bibliographic Records: Current Practices and Future Challenges in Large Research Libraries," LRTS 56, no. 3 (2012): 164.

48. Beisler and Kurt, "E-Book Workflow from Inquiry to Access," 107.

49. Ibid., 96-116.

50. Angela M. Carreño and Bill Maltarich, "Aggregation, Integration, Cooperation: The Three Imperatives of New York University's E-book Strategy," eContent Quarterly December (2013), 40, available online at www.ebrary.com/corp/newspdf/NYUDual-Hosting.pdf [accessed 29 July 2014].

51. Charles Hamaker, "Ebooks on Fire: Controversies Surrounding Ebooks in Libraries," Information Today December (2011), available online at www.infotoday.com/searcher/dec11/Hamaker. shtml [accessed 8 July 2014].

52. Ibid.

53. Carreño and Maltarich, "Aggregation, Integration, Cooperation," 40.

54. Lamothe, "Factors Influencing the Usage of an Electronic Book Collection."

55. Walters, "E-books in Academic Libraries," 205. 